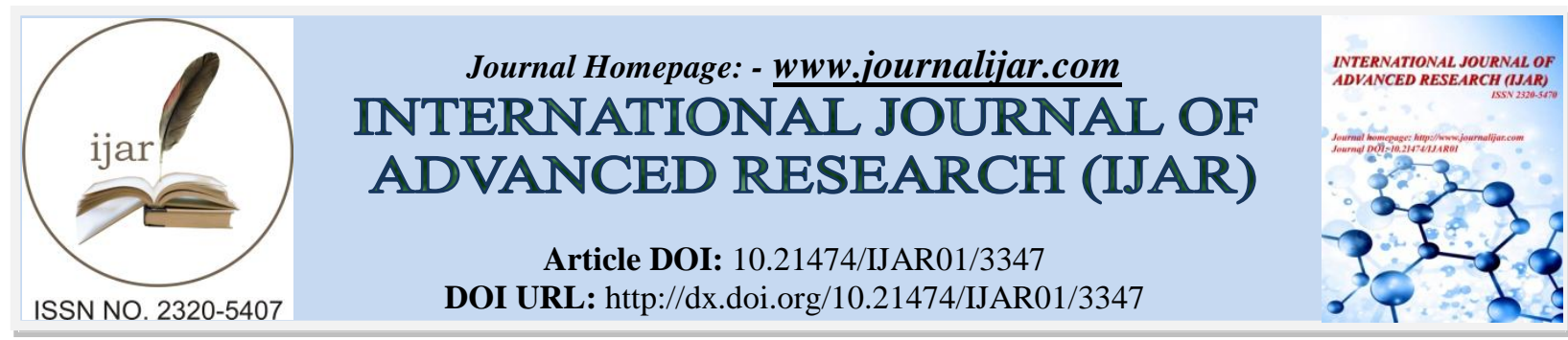

RESEARCH ARTICLE

\title{
REMOTE ISCHEMIC PRECONDITIONING AND N-ACETYLCYSTEINE IN AUTOLOGOUS OVARIAN TRANSPLANTATION IN RATS.
}

Elisa Maria Novaes Barros MS ${ }^{\mathbf{1}^{*}}$, Andrew Moraes Monteiro MS ${ }^{\mathbf{1}}$, Fernando Mateus Viegas Brandao MS ${ }^{\mathbf{1}}$, Rodrigo Paracampo Couteiro MS ${ }^{1}$, Larissa Vasconcelos de Castro MS $^{\mathbf{1}}$, Rubens Fernando Goncalves Ribeiro Junior MSc ${ }^{1}$, Tatiane Lamarao Graaf $\mathbf{M D}^{1}$, and Patrícia Brazao Cohen $\mathbf{P h D}^{2}$.

1. Laboratory of Experimental Surgery, Department of Experimental Surgery, Pará State University, Belem, Para, Brazil.

2. Department of Contemporary Amazon Parasitology, Pará State University, Belém, Para, Brazil.

\section{Manuscript Info}

Manuscript History

Received: 29 December 2016

Final Accepted: 25 January 2017

Published: February 2017

\section{Abstract}

Background: Ovarian cryopreservation is a relevant approach to fertility preservation, even though it is an invasive and still experimental procedure. Graft's vulnerability for ischemia and reperfusion injury before the neovascularization is the most important factor to determinate the viability of transplanted tissue, therefore in order to reduce this injury, many techniques were described as remote ischemic pre-conditioning (R-IPC) and early administration of $\mathrm{N}$ acetylcysteine (NAC). The aim of this study was to evaluate the effects of remote ischemic preconditioning and $\mathrm{N}$-acetylcysteine on autologous ovarian transplant in rats.

Materials and Methods: 25 female Rattus norvegicus (Wistar) were distributed into five experimental groups ( $\mathrm{n}=5)$ : (1) control (CG); (2) ovarian transplantation (GTx); (3) ovarian transplantation + R-IPC; (4) Ovarian transplantation + NAC and (5) Ovarian transplantation + RIPC + NAC. On the $15^{\text {th }}$ post-operative day, blood was collected from inferior vena cava for estradiol and progesterone serum analysis and ovarian grafts were removed for histopathology.

Results: Estradiol levels between groups showed no statistical difference, however treatment with R-IPC promoted higher progesterone levels. Ovarian graft morphology indicated that NAC treatment increased secondary follicles and promoted atretic follicles as observed in transplant group. R-IPC treatment reduced atretic follicles. Conclusions: NAC and R-IPC treatments showed protective effects regarding follicles preservation and ovarian function.

Copy Right, IJAR, 2017,. All rights reserved.

\section{Introduction:-}

The side effects and long-term consequences of chemotherapy and radiation on fertility should not be ignored, cumulative risk of premature ovarian failure can be $60 \%$ higher after alkylating chemotherapy [1]. Many diagnostic methods and treatments for cancer may involve combinations of surgery, alkylating chemotherapy, radiotherapy, and transplantation of bone morrow, which offer negative impacts on ovarian function, such as fibrosis [2], affecting

Corresponding Author:- Elisa Maria Novaes Barros MS.

Address:- Laboratory of Experimental Surgery, Department of Experimental Surgery, Pará State 
the patient's fertility. Thereafter, ovarian protection reserve and prevention of infertility became the primary quality of life issue for patients [3].

Mature oocyte and embryo banking are generally recommended before cancer treatment for fertility preservation in women. American Society for Reproductive Medicine has confirmed its safety, however, gamete or zygote banking is not a feasible option for prepubertal girls or fertile women who cannot delay therapy [4]. Thus, ovarian tissue cryopreservation is one relevant approach, even though this procedure is invasive and still experimental for young patients, requiring laparoscopic surgery [5].

Currently, it is known that graft's vulnerability for ischemia and reperfusion injury before the neovascularization is the most important factor to determinate the viability of transplanted tissue. Even though the reperfusion benefits are unquestionable, the reintroduction of oxygen in a ischemic environment initiate a complex chain of events that culminate in additional tissue injury, among which are highlighting the migration, adhesion and leukocyte activation and production of oxygen free radicals [6]. This process constitutes the main obstacle for ovarian transplant, this injury may occur after transplant, resulting in follicular death mass [7].

Many techniques were described as ischemic preconditioning (PreC) and postconditioning (PosC) which consist in short cycles of ischemia and reperfusion before or after a major ischemia period. These procedures have also been applied, successfully, in other organs as gut, myocardial and liver. These cycles can also be applied in distant organs and tissues undergoing ischemia index, and this is known as remote pre (rPreC) and post (rPosC) conditioning, that also obtained success to reduce the reperfusion trauma in many organs [8-10].

Likewise, the early application of $\mathrm{N}$-acetylcysteine (NAC) is related to beneficial effects in ovarian graft preservation [11]. This substance is a tiol of low molecular weight derivated of cysteine and acts removing reactive oxygen species, in addition to improving nitric oxide activity and regulating microcirculation [12].

Thereby, there are some literature reports about PreC and NAC positive effects on preservation of ovarian graft. Thus, the aim of this study was to evaluate the effects of remote ischemic pre-conditioning and $\mathrm{N}$-acetylcysteine on autologous ovarian transplant in rats.

\section{Methods:-}

\section{Animals:-}

25 female Wistar rats (Evandro Chagas Institute), were used at the age of 120 days and weighing 250-350g. The rats were kept under constant temperature $\left(20-22^{\circ} \mathrm{C}\right)$ in a room with controlled lighting (12/12 hours of light/dark cycle) and received water and food ad libitum. Procedures were approved by Ethics Committee on Animal Use of Pará State University (UEPA), Protocol No. 32/2015.

\section{Experimental Protocol:-}

Rats were anesthetized by intraperitoneal injection of ketamine hydrochloride $(70 \mathrm{mg} / \mathrm{kg})$ and xylazine $(10 \mathrm{mg} / \mathrm{kg})$. Then, they were placed on an electric heating pad to prevent hypothermia. Procedures were performed under surgical microscope (DF Vasconcellos 900, Brazil) set to a 10x magnification.

The animals were distributed into five study groups $(n=5)$ : (1) control: animals subjected only to midline laparotomy and a $2 \mathrm{~cm}$ incision over the inguinal fold; (2) ovarian transplantation (GTx); and (3) ovarian transplantation $+\mathrm{R}-$ IPC; (4) Ovarian transplantation + NAC and (5) Ovarian transplantation + R-IPC + NAC. On $15^{\text {th }}$ postoperative day [11], animals were euthanized with a lethal dose of previously used anesthetics.

\section{Remote Ischemic Preconditioning (R-IPC):-}

After tricotomy and polyvinylpyrrolidone iodine antisepsis, a medial laparotomy was made and the R-IPC was performed by clamping the common right iliac artery using a vascular microclamp for 15 minutes of occlusion and 15 minutes of reperfusion (Fig. 1) [13], before undergoing other procedures (oophorectomy and transplantation). 
Remote ischemic preconditioning

\begin{tabular}{|l|l|l|l|}
\hline RCIA & \multicolumn{2}{|c|}{15 days } \\
\hline Ovary & TRANSPLANT & POSTOPERATIVE & EUTHANASIA \\
\hline
\end{tabular}

Ischemia

Reperfusion

Fig. 1:- Representation of remote ischemic preconditioning. RCIA - right commom iliac artery.

\section{Oophorectomy:-}

A bilateral exeresis of meso-ovarium was made between two 5-0 silk suture ligatures. After being freed from foreign tissue, the ovary to be transplanted was washed in physiological solution $(0.9 \% \mathrm{NaCl})$.

\section{Autologous Transplantation of the Ovary:-}

After oophorectomy and washing with $0.9 \%$ saline solution, a $2 \mathrm{~cm}$ incision over the inguinal right fold was made. The femoral vessels were identified and then the right ovary was fixed among those structures using 6-0 nylon thread with no vascular anastomosis, under a microsurgical microscope.

\section{Administration of N-acetylcysteine (NAC):-}

One hour before ovarian transplantation, animals were treated subcutaneously - along the dorsum - with $1200 \mathrm{mg} / \mathrm{kg}$ of NAC [11]. The non-treated groups, namely controls, GTx and R-IPC were treated with $0.9 \%$ Sodium chloride solution at the same volume.

\section{Serum analysis:-}

On the $15^{\text {th }}$ post-operative day [11], blood samples were collected from the inferior vena cava for estradiol and progesterone serum levels (tested with kits in a solid-phase, competitive, imunofluorimetry and radioimmunoassay, respectively)

\section{Histopathology:-}

Ovarian grafts were surgically removed from the inguinal region and fixed in $10 \%$ formaldehyde. The sections were dewaxed and gradually hydrated before being stained with hematoxylin-eosin. For histological evaluation, a protocol based on D’Acampora et al (2004) [14].

\section{Statistical analysis:-}

BioEstat 5.4 was used and to confirm normal distribution samples by Kolmogorov-Smirnov test. Data are expressed as means \pm SE. ANOVA with post hoc Student's paired T-test was applied to renal function and oxidative stress, whereas the histopathological parameters by Kruskal-Wallis with post hoc Newman-Keuls. Values of $p<0.05$ were considered statistically significant.

\section{Results:-}

All animals of R-IPC+NAC died within 24 hours after the procedure. The levels of estradiol hormone between groups showed no statistical difference (Fig. 2), however, progesterone plasma levels were significantly lower in both GTx $(\mathrm{p}<0,05)$ and NAC $(\mathrm{p}<0,01)$ when compared with controls group (Fig. 3). Therefore, the R-IPC has presented the most similar levels of progesterone when compared to controls.

Ovarian graft morphology indicated that NAC treatment promoted as atretic follicles as transplant group and increased the number of secondary follicles (Fig. 4). Treatment with R-IPC promoted less atretic follicles, but primordial follicle, primary follicle, mature follicle and degenerated and functional corpora lutea were similar among groups. 
Table 1:- Histological analysis according to groups. Kruskal-Wallis (Newman-Keuls) test; *p<0.05 vs controls.

\begin{tabular}{|c|c|c|c|c|c|}
\hline Parameters & Control & GTx & R-IPC & NAC & p-value \\
\hline Primordial Follicles & 0.4 & 0.0 & 0.0 & 0.0 & 0.9343 \\
\hline Primary Follicles & 0.2 & 0.2 & 0.0 & 0.2 & 0.9340 \\
\hline Secondary Follicles & 2.4 & $1.0^{*}$ & $0.6^{*}$ & 1.4 & 0.0309 \\
\hline Mature Follicles (de Graaf) & 1.4 & 0.4 & 0.2 & 0.4 & 0.0781 \\
\hline Atretic Follicles & 0.0 & $0.8^{*}$ & 0.2 & $0.8^{*}$ & 0.0458 \\
\hline Functional Corpora Lutea & 2.2 & $0.0^{*}$ & $0.0^{*}$ & $0.4^{*}$ & 0.0086 \\
\hline Degenerated Corpora Lutea & 0.0 & 0.8 & 0.4 & 0.4 & 0.3828 \\
\hline Newly formed vessels & 0.0 & $1.0^{*}$ & $1.0^{*}$ & $1.0^{*}$ & 0.0003 \\
\hline Granulation tissue & 0.0 & 0.2 & 0.2 & 0.2 & 0.9340 \\
\hline
\end{tabular}

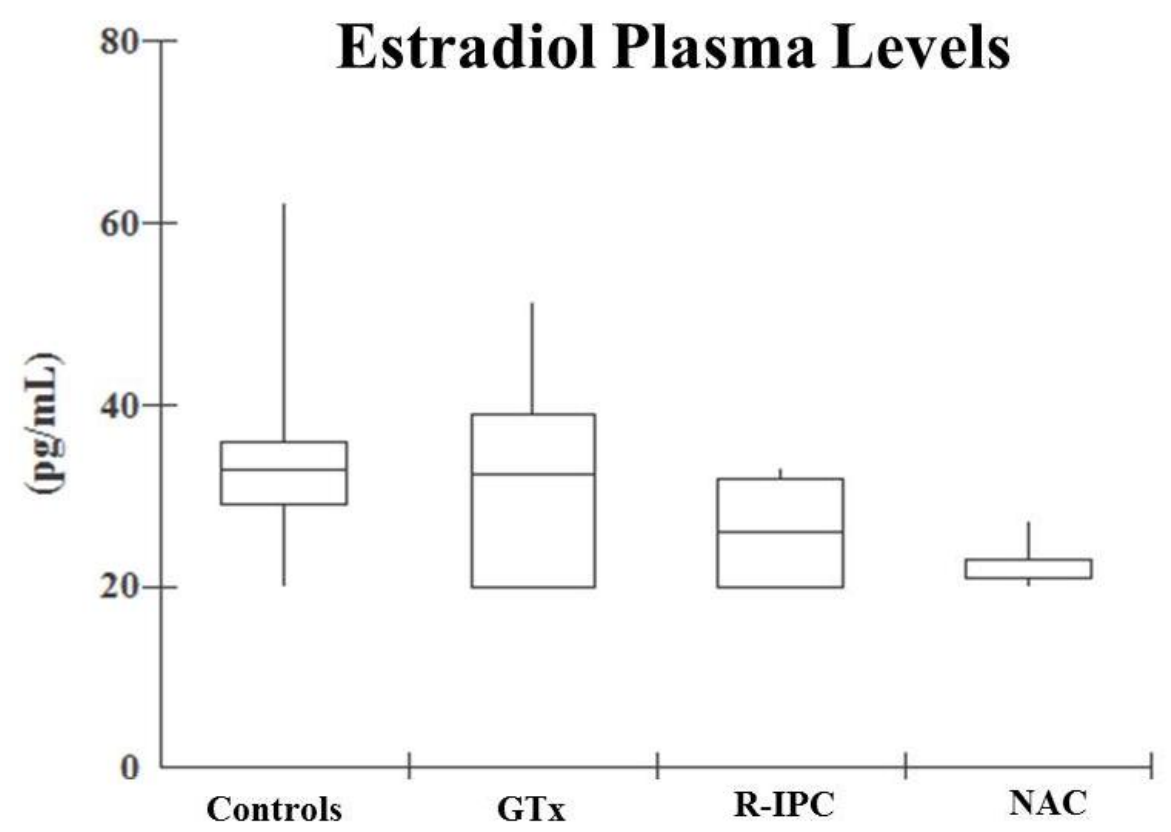

Fig. 2:- Estradiol plasma levels in pg/ml. ANOVA, $\mathrm{p}=0.2294$. 


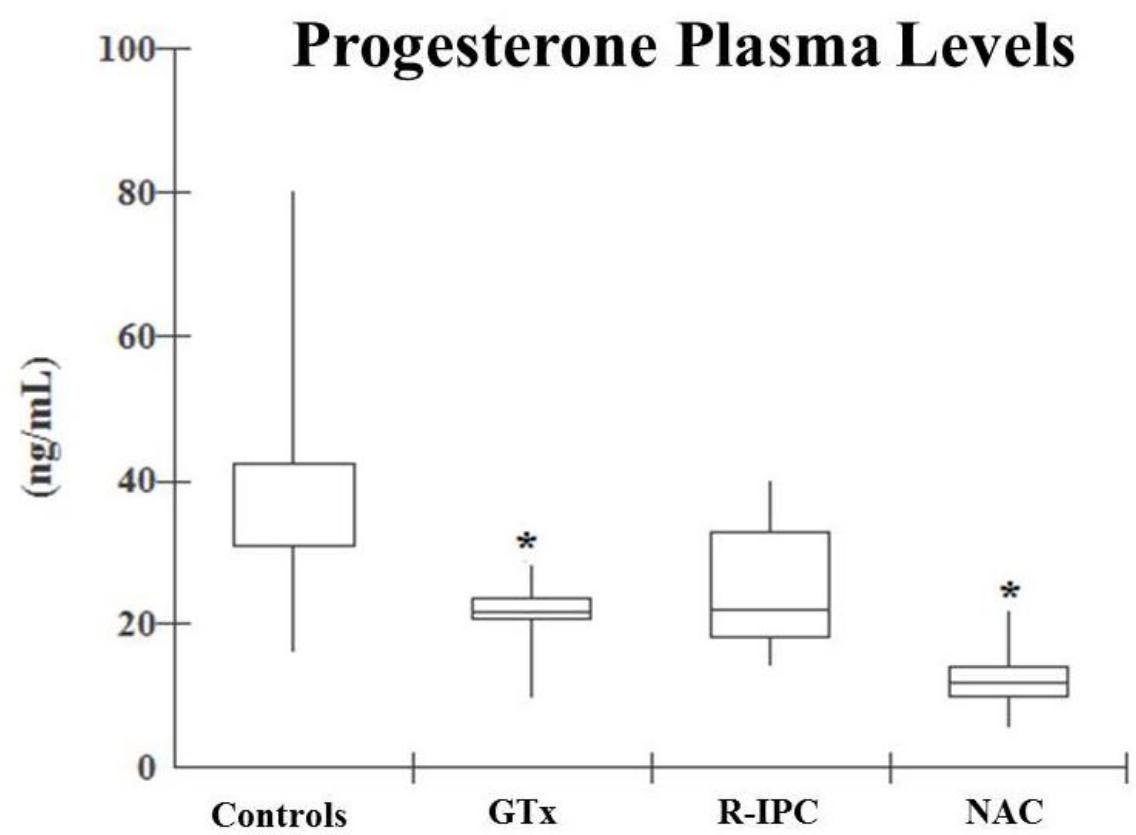

Fig. 3:- Progesterone plasma levels in $\mathrm{ng} / \mathrm{ml}$. ANOVA test with Tukey test post-hoc. ${ }^{*} \mathrm{p}<0,05$

\section{Secondary Follicles}

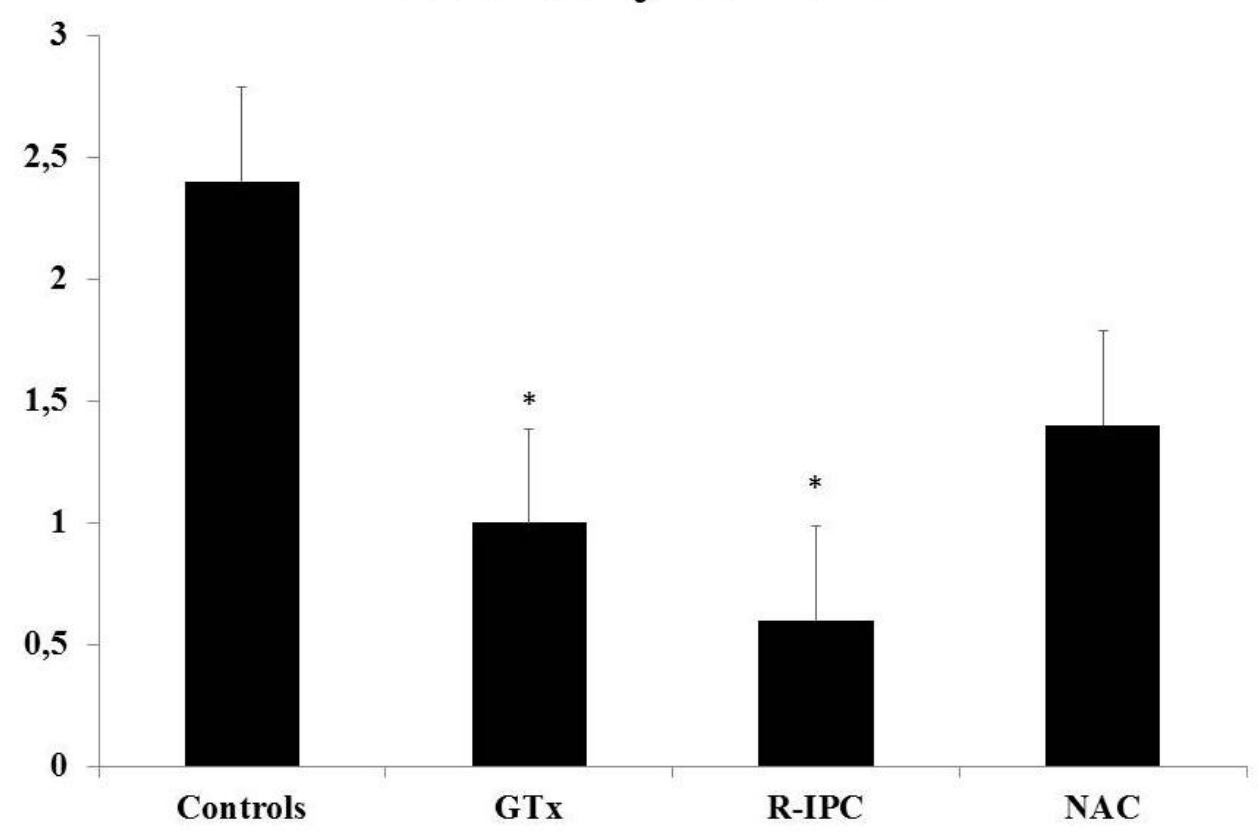

Fig. 4:- Number of Secondary follicles. Rats previously treated with R-IPC showed decrease in number of secondary follicle in graft. Kruskal-Wallis (Newman-Keuls) test; *, p $<0.05$ vs controls.

\section{Discussion:-}

Successful fertility preservation through ovarian graft transplantation depends mainly on rapid reestablishment of vascularization and perfusion to the graft. Decreasing post transplantation hypoxia will protect the primordial follicle reserve and ensure the highest chance for retrieving mature oocytes for in vitro fertilization [14]. 
Regarding transplantation site, several were described: retroperitoneum [13,16,17], kidney capsules [4], greater omentum [18], fat pad [19] and inguinal region[20], to transplant the graft next to larger vessels, in areas that promote better vascularization, is important to allow its viability. Therefore, in the present study the authors choose to perform the technique of autotransplantation to the inguinal region that, according to Ceschin et al (2004) [20], demonstrated functionality and viability in $100 \%$ of analyzed slices.

In the present study, the effects of NAC and R-IPC on rat ovarian tissue after heterotopic autotransplantation were investigated. The association of both treatments was unviable, leading to death of all five animals from R-IPC+NAC group, possibly, a collateral effect of an overdose of NAC, which has been associated in other studies with decrease in prothrombin index and anaphylactoid reactions [21]. Therefore, it has been demonstrated that NAC significantly inhibits the protective mechanism of pre-conditioning for organs such as the myocardium [22].

The results also indicated that treatment with R-IPC, significantly improved the hormonal levels of progesterone, although did not reach the same level found on control group. R-IPC leads to earlier re-initiation of ovarian activity and increases the number of cycles in fresh graft, which can be related to a compensatory effect after I/R injury during the transplant when growth factors are produced to establish graft angiogenesis. The established neovascularization may stimulate the graft to re-initiate its function [23] which justifies the findings.

Damous et al (2009) [16] when studying the effect of R-IPC on rat's estradiol serum levels after ovary transplantation concluded that R-IPC increased estradiol levels in most animals, reaching an average of $65 \mathrm{pg} / \mathrm{mL}$. This data was not confirmed by the present study (graphic 1) because, according to Damous, this increase was seen 72 hours post transplantation returning to lower levels similar to the other groups at seven days. Therefore, as the euthanasia, in this study, was performed at the $15^{\text {th }}$ day such increase had already ceased.

In addition, others studies demonstrated that 21 days after transplantation, serum FSH levels reaches the same as the fresh control [17], explaining why the serum estradiol levels were similar. However, Mahmoodi et al (2015) [12] postulated that the treatment with n-acetylcisteine actually improved estradiol concentration at the $28^{\text {th }}$ postoperative day because of its anti-oxidant properties, these discordant results might be explained by the difference on treatment protocol used (lower doses administered for a longer period) or variations in hormone measurements induced by natural animal diversity or by environmental stress or handling, that could have led to inconclusive results.

As our study indicated, the number of follicles in the autografted groups compared with the control groups decreased considerably, which confirms previous reports [23,24]. This could be explained because in the first days of transplantation, granulosa cells and oocytes, particularly in developing follicles, undergo apoptosis as a result of ischemia and reperfusion injury induced by free radicals and lipid peroxidation. This can lead to the degeneration and atresia of follicles and disruption in folliculogenesis and oogenesis, which eventually decreases the ovary volume and size and also the number of follicles [12].

Meanwhile, treatment with NAC resulted in a higher number of secondary follicles compared with the GTx and RIPC groups, through preventing initial tissue degeneration and follicle atresia as a result of its ability to delay or inhibit apoptosis of ovary cells in the time of hypoxia and also to reduce the ischemia-reperfusion injury through its antioxidant ability and increasing the glutathione reservoir [12].

Although the association of NAC and R-IPC was not possible in the study, this still represents an interesting result, as it will serve as an example so that such protocol will not be used in other researches, which creates possibilities for new studies with lower concentrations of NAC or reduced I/R time.

\section{Conclusion:-}

NAC and R-IPC separately had protective effects towards follicles and ovarian function preservation. However, further examinations are needed to translate our results to clinical trials of human ovarian transplantation, along with suitable modifications as oral administration, which provide an easier route of administration in human patients.

\section{Acknowledgment:-}

The authors declare no conflict of interest 


\section{Disclosure:-}

All authors declare no financial and personal relationships with other people or organizations.

\section{References:-}

1. Marleen AE, Kaaij VD, Heutte N, Meijnders P, Abeilard-Lemoisson E, Spina M, Moser EC et al. Premature Ovarian Failure and Fertility in Long-Term Survivors of Hodgkin's Lymphoma: A European Organisation for Research and Treatment of Cancer Lymphoma Group and Groupe d'E' tude des Lymphomes de l'Adulte Cohort Study. J Clin Oncol, 2012, 30(3):291-9. DOI: 10.1200/JCO.2011.37.1989

2. Knight S, Lorenzo A, Maloney AM, Srikanthan A, Donen R, Greenblatt E, Gupta A. An Approach to Fertility Preservation in Prepubertal and Postpubertal Females: A Critical Review of Current Literature. Pediatr Blood Cancer, 2015,62:935-9. DOI: 10.1002/pbc.25440

3. Hadassa Roness H, Kashi O, Meirow D. Prevention of chemotherapy-induced ovarian damage. Fertil Steril, 2016, 105(1):20-9. DOI: 10.1016/j.fertnstert.2015.11.043

4. Lee J, Kong HS, Kim EJ, Youm HW, Lee JR, Suh CS, Kim SH et al. Ovarian injury during cryopreservation and transplantation in mice: a comparative study between cryoinjury and ischemic injury. Hum. Reprod, 2016; 31(8): 1827-37. DOI: 10.1093/humrep/dew144

5. Wallace WHB, Kelsey TW, Anderson RA. Fertility preservation in pre pubertal girls with cancer: the role of ovarian tissue cryopreservation. Fertil Steril, 2016, 105(1):6-12. DOI: http://dx.doi.org/10.1016/j.fertnstert.2015.11.041

6. Bonservizi WGS, Koike MK, Saurim R et al. Ischemic Preconditioning and Atenolol on Lung Injury After Intestinal Ischemia and Reperfusion in Rats. Transplantation Proceedings, 2014, 46:1862-6. DOI: http://dx.doi.org/10.1016/j.transproceed.2014.05.054

7. Michaeli J, Weintraub M, Gross E et al. Fertility Preservation in Girls. Obstetrics and Gynecology International, 2012. DOI: http://dx.doi.org/10.1155/2012/139193.

8. Yamaki VN, Gonçalves TB, Coelho JVB et al. Efeito protetor do per-condicionamento isquêmico remoto nas lesões da síndrome de isquemia e reperfusão renal em ratos. Rev Col Bras Cir. 2012, 39(6):529:33. DOI: http://dx.doi.org/10.1590/S0100-69912012000600014

9. Jiang BT, Chen QZ, Guo ZH, Zou W, Chen X, Zha WL. Ischemic post-conditioning attenuates renal ischemic reperfusion injury via down-regulation of toll-like receptor 4 in diabetic rats. Ren Fail. 2016, 5:1-7. DOI: 10.1080/0886022X.2016.1214148

10. Zheng W, Zhang Z, Liu S, Bi J, Zhang J, Du L, Ding X, Liu C. Remote ischemic conditioning protects against acetaminophen-induced acute liver injury in mice. Hepatol Res. 2016, 17. DOI: 10.1111/hepr.12702.

11. Amorim EMG, Damous LL, Durando, MCS et al. N-acetylcysteine improves morphologic and functional aspects of ovarian grafts in rats. Acta Cir Bras. 2014;(29), Supl. 3. DOI: http://dx.doi.org/10.1590/S010286502014001700005.

12. Mahmoodi M, Mehranjani MS, Shariatzadeh SMA, Eimani H, Shahverdi A. N-acetylcysteine improves function and follicular survival in mice ovarian grafts through inhibition of oxidative stress. Reprod Biomed Online, 2015; 30:101-10. DOI: 10.1016/j.rbmo.2014.09.013.

13. Damous LL, Silva SM, Simões RS et al. Remote Ischemic Preconditioning on Neovascularization and Follicle Viability on Ovary Autotransplantation in Rats. Transplant. Proc., 2008; 40:861-64. DOI: 10.1016/j.transproceed.2008.02.065.

14. d'Acampora AJ, Tramonte R, Manoel FS et al. Análise histológica da viabilidade do transplante autólogo de hemi-ovário em retroperitônio de ratos. Acta Cir Bras, 2004; 19(4). DOI: http://dx.doi.org/10.1590/S010286502004000400007

15. Cohen Y, Dafni H, Avni R, Tal Raz, DVM, Inbal Biton DACT, Hemmings B, Neeman M . In search of signaling pathways critical for ovarian graft reception: Akt1 is essential for long-term survival of ovarian grafts. Fertil Steril, 2014; 101 (2). DOI: http://dx.doi.org/10.1016/j.fertnstert.2013.10.007

16. Damous LL, Silva SM, Carbonel APF, Simões RS, Simões MJ, EFS Montero. Effect of Remote Ischemic Preconditioning on Rat Estradiol Serum Levels and Follicular Development After Ovarian Transplantation. Transplant. Proc., 2009; 41:830-33.DOI: 10.1016/j.transproceed.2009.01.070

17. Damous LL, Silva SM, Carbonel AAF, Simões MJ, Baracat EC, Montero EFS. Progressive Evaluation of Apoptosis, Proliferation, and Angiogenesis in Fresh Rat Ovarian Autografts Under Remote Ischemic Preconditioning. Reproductive Sciences, 2015, DOI: 10.1177/1933719115620493. 
18. Brito NMB, Torres IO, Silveira EL, Santos LLT. Study about the feasibility of ovarian graft in rats' omentum pouch, using cyclosporine A. Acta Cir Bras, 2005; 20 (2). DOI: http://dx.doi.org/10.1590/S010286502005000200013

19. Flesken-Nikitin, A., Harlan, B. A., Nikitin, A. Y. Transplantation Into the Mouse Ovarian Fat Pad. J. Vis. Exp. 2016,(115), e54444, DOI:10.3791/54444.

20. Ceschin AP, Biondo-Simões MLP, Thomaz BAC, Totsugui J. Indirect hormonal evaluation and study of the follicles preservation in the ovarian transplantation tissue in rats inguinal region. Acta Cir Bras [serial online] 2004 Jan- Feb;19(1). DOI: http://dx.doi.org/10.1590/S0102-86502004000100004

21. Sandilands EA, Bateman DN. Adverse reactions associated with acetylcysteine. Clin Toxicol, 2009; 47(2). DOI:10.1080/15563650802665587.

22. Oliveira DM, Gomes ES, Mussivand T, Fiorelli AI, Gomes OM. Efeitos da N-acetilcisteína no precondicionamento isquêmico: estudo em corações isolados de ratos. Rev Bras Cir Cardiovasc, 2009; 24(1): 23-30. DOI: http://dx.doi.org/10.1590/S0102-76382009000100006

23. Damous LL, Silva SM, Renato Antônio Migliano Lopes RAM, Sakano CRSB, Simões MJ, Montero EFS. Study on the vaginal smear of rats submitted to autologous ovarian transplant. Impact of remote ischemic preconditioning. Acta Cir Bras, 2009; 24 (5). DOI: http://dx.doi.org/10.1590/S0102-86502009000500009.

24. Taheri MA, Valojerdi MR, Ebrahimi B. Intramuscular Autotransplantation of Vitrified Rat Ovary Encapsulated with Hyaluronic Acid Hydrogel. Biopreserv Biobank, 2016; 14(2):114-21. DOI: 10.1089/bio.2015.0021

25. Israely $\mathrm{T}$, Nevo $\mathrm{N}$, Harmelin A, Neeman M, Tsafriri A. Reducing ischaemic damage in rodent ovarian xenografts transplanted into granulation tissue. Human Reproduction, 2006; 21(6): 1368-79. DOI: 10.1093/humrep/del010 